laboratory which is in Heidelberg in Germany, but is a serious setback. Moreover, the schemes being canvassed to win Italy back into the fold raise questions about the longterm function of the laboratory that are certain to give pause to other member states. That is why it is important that EMBL should not be confused with the European Molecular Biology Organization (EMBO), also based at Heidelberg, which runs workshops and offers fellowships throughout Europe, and which publishes the excellent EMBO Journal. EMBL, founded in 1974, is an offshoot of EMBO, but is constitutionally independent of the organization.

The case for EMBL was controversial from the outset. The model was that of the European Laboratory for Particle Physics (CERN) in Geneva, whose existence is predicated on the belief that it can take on projects too big for individual members states to tackle. Constitutionally, EMBL thus owes its existence to a treaty between the members states, whose annual contributions to the cost are fixed by formula. At the beginning (in the early 1970 s), there were cogent objections from potential members that molecular biology differs from high-energy physics in being a relatively small-scale enterprise and not so much a field of study in its own right, as a technique destined to spread throughout biology. But there were counter-arguments: Twenty years ago, the nucleotide sequence of $E$. coli was commonly offered as a large scale goal, as was the study of biomolecular structure. Now, EMBL is Europe's custodian of the huge volume of sequence data now accumulating, its outstation at the Synchrotron Laboratory at Grenoble a symbol of its commitment to structures.

But the old objection persists. If anything, molecular biology has turned out to be more pervasively a part of biology in general than even the critics imagined twenty years ago. That is not to say that EMBL's core laboratory at Heidelberg serves no purpose. On the contrary, it maintains several energetic research groups which, because of their international composition, have an incidentally beneficial effect on the spread of molecular biology through Europe. The benefits may be expensive, but at least they are tangible. If Italy pulls out, the others should be prepared to soldier on at least until Dr George Kafatos, the new director, has a chance to settle in.

The hope of keeping Italy sweet by offering to set up outstations in Italy (see page 205) is, on the other hand, misguided. No doubt part of the Italian suspicion that it derives less benefit than others from the present set-up centres around last year's decision to transfer the sequence databases to a new centre at Cambridge, England (with the help of Wellcome money), but Italy's commitment to the International Centre of Genetic Engineering and Biotechnology at Trieste may also have influenced the decision. But the plain truth is that the proliferation of outstations would further weaken EMBL's claim on public attention, turning it from a research organization into a way of recycling national funds into internationally supported national laboratories. What EMBL needs is a research programme, not a funding mechanism.

\section{The price is wrong!}

\section{Eurotunnel's high prices for crossing the English Channel by motor car are disappointingly high.}

THE legend of the Channel Tunnel (connecting Britain and France) has its roots in the eighteenth century. When tunnellers were skilled (but not particularly skilled) at cutting tunnels only through coal-seams, and when the standard means of traction was the horse, the project could have been laughed out of court on technical grounds, but was not; the British fear that Napoleon would march his armies beneath the Channel (otherwise La Manche) was a more potent reason for abandoning the project. After the Congress of Vienna brought peace to Europe and with the arrival of steam locomotion, the project was revived, a few hundred metres of tunnel were dug beneath the sea at Dover and then again abandoned when the organizers ran out of money. But now a Channel Tunnel exists and will open for service in a month or so. The first passengers will travel with their motor cars, but a passenger train service will begin in June or thereabouts. So where are the signs of general rejoicing such a development should command?

Sadly, there is very little rejoicing, and what there is has been dampened by the announcement last week by Eurotunnel, the Anglo-French company franchised to operate the tunnel, of its tariffs for carrying motor vehicles beneath the Channel. Like the ship ferries that now ply the Channel, Eurotunnel plans different charges at different times of the year. Broadly speaking, Eurotunnel will charge drivers a little less than the ferry companies to cross the Channel at peak summer weekends ( $£ 310$ against $£ 320$ ), but considerably more at other times ( $£ 220$ against roughly $£ 130$ ). For Eurotunnel, that seems a recipe for an awkward seasonal fluctuation of demand; novelty and the slightly lower price will ensure that its summer weekends are busy, but the ferries will take the lion's share of the traffic at other times. That seems unwise when the business hangs on loading motor cars onto untried transporters - but luckily, that is Eurotunnel's business, not that of either British or French taxpayers.

The more serious disappointment is that the fares are so high. The reasons are plain enough; Eurotunnel was originally meant to cost $£ 4.8$ billion, but the final cost will be more than twice as much. At these rates, the Channel ports from which the ferries operate can sleep easily again, confident that Eurotunnel will capture a smaller part of the cross-Channel vehicle business than they had feared. And that is a misfortune for others on both sides of the Channel because Europe is much in need of a way of making Britain more a part of the rest of Europe. The only hope now is that the cost of travelling through Eurotunnel by train, still to be declared, can be kept substantially below the air fares charged by the rapacious airlines operating between Britain and the mainland. That way, some social benefit may be won from the investment of all the technology that has gone into Eurotunnel. 